\title{
The analysis of suicide deaths in the Lublin macroregion in the years 2000-2010
}

\section{Analiza zgonów z powodu samobójstw w makroregionie lubelskim w latach 2000-2010}

\author{
Hanna Skórzyńska¹, Małgorzata Włoch², Teresa B. Kulik¹, Anna Pacian¹, Marlena Krawczyk-Suszek³ \\ Monika Kaczoruk ${ }^{1}$
}

${ }^{1}$ Department of Public Health, Faculty of Health Sciences, Medical University of Lublin, Lublin, Poland Head of the Department: Prof. Teresa B. Kulik MD, PhD

${ }^{2}$ Higher Professional Police School, Szczytno, Poland

Head of the School: Piotr Bogdalski

${ }^{3}$ Chair of Physiotherapy, University of Information Technology and Management, Rzeszow, Poland

Head of the Chair: Dr. Helena Bartyzel-Lechforowicz MD, PhD

Key words: suicides, suicide breakdown, suicide risk.

Słowa kluczowe: samobójstwa, podział samobójstw, ryzyko samobójstw.

\begin{abstract}
Introduction: Suicide is a serious social problem of global and national significance. Although Poland is a country with a relatively low suicide risk, it is the cause of death of several thousand people every year, roughly the same number as those who perish in road accidents.

Aim of the research: To trace the number of suicidal deaths in the Lubelskie Region over a period of 11 years, and to analyse the breakdown of suicides and the tendencies of this phenomenon in the macroregion.

Material and methods: The data were obtained with the permission of the Lublin Provincial Police Commander from the Lublin Provincial Police Headquarters. The data included the statistics of suicidal deaths from 2000 to 2010 in the Lublin Macroregion.

Results and conclusions: Male sex is prevalent for suicides (86.4\%) over female sex (14.6\%). Suicides have most often concerned persons at the age of 30-50 (36.6\%). Young people up to 20 take the fourth place in the age category (6.8\%). The most exposed to risk of suicide are individuals with primary education (26.5\%). The overall number of suicides in the Lubelskie Region has slightly risen in the past few years, although this differs by location within the macroregion. Increasing risk of suicide is a challenge for the prevention of the phenomenon, which should take suicidal risk factors into consideration. The most common cause of suicide It was a mental illness (15.1\%). Family problems were the second cause of suicide. Economic problems were the cause of an average $5.1 \%$ of all suicides.
\end{abstract}

\section{Streszczenie}

Wprowadzenie: Samobójstwo stanowi poważny problem społeczny o globalnym znaczeniu. Chociaż Polska jest krajem o stosunkowo niewielkim ryzyku samobójstw, liczba tych incydentów okazuje się niemal identyczna jak liczba ofiar wypadków drogowych.

Cel pracy: Analiza liczby zamachów samobójczych powodujących zgony w województwie lubelskim w ciągu 11 lat. Materiał i metody: Materiał do badań uzyskano za zgodą Wojewódzkiego Komendanta Policji z Komendy Wojewódzkiej Policji w Lublinie. Analizowane dane dotyczyły lat 2000-2010. Poddano je analizie statystycznej, koncentrując się na takich zmiennych, jak: wiek, płeć, miejsce zamieszkania, wykształcenie, metody popełnienia samobójstwa oraz przyczyny zachowań samobójczych.

Wyniki i wnioski: Mężczyźni częściej $(86,4 \%)$ niż kobiety $(14,6 \%)$ podejmują próbę samobójczą. Samobójstwa najczęściej dotyczyły osób w wieku 30-50 lat (36,6\%). Młodzież do 20. roku życia znajduje się na czwartym miejscu pod względem częstości samobójstw w kategorii wiekowej $(6,8 \%)$. Najbardziej narażone na samobójstwo są osoby z wykształceniem podstawowym (26,5\%). Ogólna liczba samobójstw w województwie lubelskim nieznacznie wzrosła w ciągu ostatnich kilku lat, choć różni się od lokalizacji w obrębie makroregionu. Zwiększająca się liczba zamachów samobójczych stanowi wyzwanie dla profilaktyki i promocji zdrowia psychicznego oraz dla zapobiegania temu zjawisku. Działania zapobiegawcze powinny się koncentrować na głównych czynnikach ryzyka samobójstw. Najczęstszą przyczyną samobójstw była choroba psychiczna $(15,1 \%)$. Problemy rodzinne stanowiły drugą przyczynę samobójstw. Problemy ekonomiczne były przyczyną średnio 5,1\% wszystkich samobójstw. 


\section{Introduction}

Suicide is a serious social problem of global and national significance. Although Poland is a country with a relatively low suicide risk, it is the cause of death of several thousand people every year, roughly the same number as those who perish in road accidents. Suicide rates in Poland are average, and the country ranks in the middle of the list in global suicide statistics, with about 15 suicides per 100,000 people [1].

Suicide, as a social problem, must be perceived as a manifestation of negative phenomena and even social pathology [2]. It is a dynamic phenomenon that changes with time, a complex problem triggered by both social and individual factors.

One of the objectives of suicidology is to explain suicide attempts in the context of a diverse range of factors: demographic, economic, political, social, psychological, and biological. Finding the causal relationships between distinct factors and suicide enables the suicidologist to prepare forecasts. The ultimate goal of such an analysis is to provide a scientific foundation for preventive programmes that could reduce the extent of this tragic phenomenon [2].

In pathology prevention it is important to define the level of exposure to a given phenomenon, and also to determine a group of people, an area, or community, in which a given pathology is the most prevalent [3] A number of programmes for suicide prevention focus on providing early assistance to people most at risk due to mental disorders or psychological crises they experi- ence as they face difficult life situations. Mental health promotion programmes may be one way to prevent suicide, as they provide assistance in acquiring the ability to make personal progress and manage negative life events [4]. It is therefore essential to analyse this phenomenon over time, as it allows the identification of current risk groups and the suicidogenic factors at play in society.

\section{Aim of the research}

The objective of this paper is to trace the number of suicidal deaths in the Lubelskie Region over a period of 11 years, from 2000 until the end of 2010, and to analyse the breakdown of suicides and the tendencies of this phenomenon in the macroregion.

\section{Material and methods}

The data were obtained with the permission of the Lublin Provincial Police Commander from the Lublin Provincial Police Headquarters. The data included the statistics of suicidal deaths from 1 January 2000 to 31 December 2010 in the Lublin Macroregion. The data were subjected to statistical analysis focussing on age, sex, place of residence, education, the method of committing suicide, and the causes of suicidal behaviours.

\section{Results and discussion}

The initial step in the data analysis was to determine the total number of suicides in the respective years and to compare it with the data for the whole of Poland (Table 1, Figure 1).

Table 1. Suicides in the Lubelskie Region and Poland

\begin{tabular}{|c|c|c|c|c|c|c|}
\hline \multirow[t]{2}{*}{ Year } & \multicolumn{3}{|c|}{ Region Lublin } & \multicolumn{3}{|c|}{ Poland } \\
\hline & $\begin{array}{l}\text { Deaths by } \\
\text { suicide }\end{array}$ & $\begin{array}{c}\text { People } \\
\text { (per 100,000) }\end{array}$ & $\begin{array}{c}\text { Mortality } \\
\text { rate from suicide }\end{array}$ & $\begin{array}{l}\text { Deaths by } \\
\text { suicide }\end{array}$ & $\begin{array}{c}\text { People } \\
\text { (per 100,000) }\end{array}$ & $\begin{array}{l}\text { Crude mortality } \\
\text { rate (per } 100,000)\end{array}$ \\
\hline 2000 & 259 & 2206,2 & 11.7 & 4947 & 38253,9 & 12.9 \\
\hline 2001 & 271 & 2201,7 & 12.3 & 4971 & 38242,2 & 13.0 \\
\hline 2002 & 288 & 2197,0 & 13.1 & 5100 & 38230,1 & 13.3 \\
\hline 2003 & 356 & 2191,2 & 16.2 & 4634 & 38191,5 & 12.1 \\
\hline 2004 & 352 & 2185,1 & 16.1 & 4893 & 38174,0 & 12.8 \\
\hline 2005 & 309 & 2179,6 & 14.2 & 4621 & 38157,1 & 12.1 \\
\hline 2006 & 277 & 2172,8 & 12.7 & 4090 & 38125,0 & 10.7 \\
\hline 2007 & 231 & 2166,2 & 10.7 & 3530 & 38115,6 & 9.3 \\
\hline 2008 & 299 & 2161,8 & 13.8 & 3964 & 38135,9 & 10.4 \\
\hline 2009 & 309 & 2157,2 & 14.3 & 4384 & 38173,3 & 11.5 \\
\hline 2010 & 285 & 2178,6 & 13.1 & 3063 & 38529,9 & 7.9 \\
\hline \multicolumn{4}{|c|}{${ }^{*} M=13.47: S D=1.7$} & \multicolumn{3}{|c|}{${ }^{*} M=11.47 ; S D=1.72$} \\
\hline
\end{tabular}

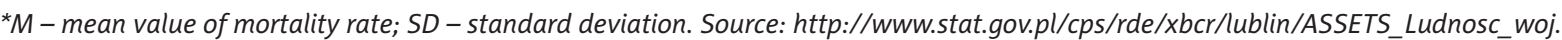
lubelskie_2011\%281\%29.pdf, http://www.stat.gov.pl/cps/rde/xbcr/gus/LUD_ludnosc_stan_str_dem_spo_NSP2011.pdf. 
By means of the statistics provided by the Central Statistical Office and the Statistical Office in Lublin, the mortality rate was calculated, which allowed the subjective evaluation of the dynamics of suicidal deaths in the Lublin region as well as in Poland [5-8]. The analysis of the line chart comparing the value of the mortality rates in the Lublin region and in Poland indicates a slightly decreasing tendency among the suicidal rates in the whole country as compared to the increase in suicidal deaths in the Lublin Region. The analysis of two extreme periods - the years 2000 and 2010 - shows the direction of the phenomenon of suicides under examination. For the Lublin region the mortality rate in 2000 was 11.7, while in 2010 the number of suicidal deaths increased to 13 people out of 100,000 residents. The opposite tendency can be observed in Poland, where the mortality rate in 2000 was 13 people per 100,000 residents, while in the period until 31 December 2010 the number of suicidal deaths fell to approximately 8 people per 100,000 residents. The deviation of the value of the mortality rate in particular years slightly differs from its average rate (Lublin region $-\mathrm{SD}=1.7$; Poland $-\mathrm{SD}$ $=1.72$ ), whose value is comparable for the Lublin region and Poland (Lublin Region - M = 13.47; Poland $-\mathrm{M}=11.47)$. The year $2003 \mathrm{had}$ a different influence on both groups of variables. In this period of time, there was an increase of suicidal deaths in the Lublin Region from 13 people per 100,000 residents in 2002 to approximately 16 people per 100,000 residents. At the same time, in Poland there was a slight decrease in the number of suicidal deaths by 1 person per 100,000 residents (mortality rate: 13.1/100,000 (2002) and 12.1/100,000 (2003)). In 2007 the value of mortality rate fell from 12.7 to 10.7 per 100,000 residents in Lubelskie Region and 10.7 to 9.3 per 100,000 residents in Poland. According to the dats included in the brochure published by the Central Statistical Office Basic Information on the Demographic Development of Poland until 2012, the Lublin region belonged to one of the four regions where a rapid decrease in population was observed $[5,9,10]$. The exact relative numbers of suicidal deaths in the area of the Lublin region and in Poland are calculated by the Central Statistical Office, whereas the rough results of the mortality rates are presented in Table 1.

Further, in order to analyse the distribution of suicides over the study period in respective areas of the Lubelskie Region, a collation of data in twenty districts of the Region was prepared (Tables 2 and 3).

Over the period of 11 years, the largest number of deaths was recorded in the Lublin District $-13.7 \%$ of the total number of suicidal deaths in the Lublin Region, which amounts to the deaths of approximately 22 people per 100,000 residents according to the average value of the mortality rate. The lowest percentage was observed in the Janów District (1\%) - the death

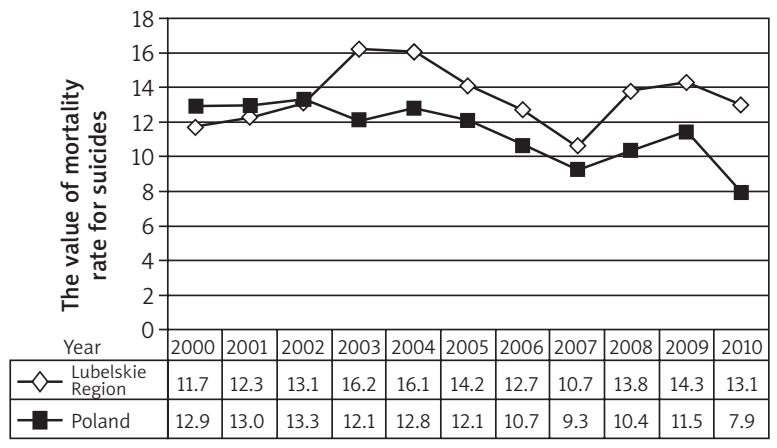

Figure 1. Mortality rate for suicides in the Lubelskie Region and in Poland in the years 2000-2010

of 1 person per 100,000 residents. The mortality rate indicated suicidal deaths of approximately 16 people per 100,000 residents in the Zamość District and comparable suicidal death rates of approximately 13 people per 100,000 residents in the districts of Biała Podlaska and Chełm. These districts are characterised by a similar area and population. The lowest percentage of suicidal deaths was observed in the Łęczna (1.6\%; approx. 2 people/100,000), Parczew (1.4\%; approx. 2 people/100,000) and the aforementioned Janów Lubelski District (1\%). It should be emphasised that the Lublin District is the largest in the region, while the Janów District is one of the smallest, which explains the considerable difference in the number of suicides.

In Biała Podlaska, the highest suicide rate was recorded in 2000 (33) and in 2003 (35), while the lowest was observed in 2010 (9). From 2003, the number of deaths by suicide was consistently decreasing. In the Biłgoraj District, the year 2003 stood out with 21 suicides recorded, while the remaining years saw a lower rate. In Chełm, the highest suicide rate was observed from 2000 to 2005 and was 34 deaths on average. From 2006, the number of deaths decreased twofold, and this trend continued until 2010. In the Hrubieszów District, the number of suicides was consistently rising until 2010. The highest suicide rate was recorded in 2002 (24), 2004 (25), and 2010 (22), which was alarming, considering that this district is one of the smallest in the Lubelskie Region. In the Janów Lubelski District, the highest suicide rate was observed in 2000 (6). The following years show a continuous decrease in the number of deaths by suicide, which fell to zero in 2010.

In the Krasnystaw District, the number of deaths over the 11-year period remained at a similar level. A particularly significant year was 2004, with three times more suicides (31) than in any of the other years. In the Kraśnik District, from 2003, over the following 2 years, and in 2007 and 2008, the suicide rate was roughly three times higher than that for the remaining years of the study period. In the Lubartów 
Table 2. Deaths by suicide in individual districts of the Lubelskie Region in 2000-2010

\begin{tabular}{|c|c|c|c|c|c|c|c|c|c|c|c|c|}
\hline \multirow[t]{2}{*}{ District } & \multicolumn{2}{|c|}{2000} & \multicolumn{2}{|c|}{2001} & \multicolumn{2}{|c|}{2002} & \multicolumn{2}{|c|}{2003} & \multicolumn{2}{|c|}{2004} & \multicolumn{2}{|c|}{2005} \\
\hline & $n$ & $\%$ & $n$ & $\%$ & $n$ & $\%$ & $n$ & $\%$ & $n$ & $\%$ & $n$ & $\%$ \\
\hline Biała Podlaska (1) & 33 & 12.7 & 28 & 10.3 & 30 & 10.4 & 35 & 9.8 & 22 & 6.3 & 25 & 8.1 \\
\hline Bitgoraj (2) & 17 & 6.6 & 15 & 5.5 & 11 & 3.8 & 21 & 5.9 & 14 & 4.0 & 18 & 5.8 \\
\hline Chełm (3) & 36 & 13.9 & 35 & 12.9 & 37 & 12.8 & 32 & 9.0 & 36 & 10.2 & 31 & 10.0 \\
\hline Hrubieszów (4) & 15 & 5.8 & 12 & 4.4 & 24 & 8.3 & 16 & 4.5 & 25 & 7.1 & 16 & 5.2 \\
\hline Janów Lubelski (5) & 6 & 2.3 & 2 & 0.7 & 4 & 1.4 & 4 & 1.1 & 3 & 0.9 & 3 & 1.0 \\
\hline Krasnystaw (6) & 14 & 5.4 & 9 & 3.3 & 10 & 3.5 & 10 & 2.8 & 31 & 8.8 & 5 & 1.6 \\
\hline Kraśnik (7) & 7 & 2.7 & 7 & 2.6 & 8 & 2.8 & 21 & 5.9 & 20 & 5.7 & 19 & 6.1 \\
\hline Lubartów (8) & 5 & 1.9 & 22 & 8.1 & 18 & 6.3 & 16 & 4.5 & 29 & 8.2 & 26 & 8.4 \\
\hline Lublin (9) & 31 & 12.0 & 33 & 12.2 & 22 & 7.6 & 48 & 13.5 & 46 & 13.1 & 45 & 14.6 \\
\hline Łęczna (10) & 11 & 4.2 & 5 & 1.8 & 2 & 0.7 & 3 & 0.8 & 5 & 1.4 & 7 & 2.3 \\
\hline Łuków (11) & 12 & 4.6 & 8 & 3.0 & 23 & 8.0 & 24 & 6.7 & 23 & 6.5 & 17 & 5.5 \\
\hline Opole Lubelskie (12) & 6 & 2.3 & 13 & 4.8 & 3 & 1.0 & 10 & 2.8 & 6 & 1.7 & 3 & 1.0 \\
\hline Parczew (13) & 4 & 1.5 & 3 & 1.1 & 6 & 2.1 & 4 & 1.1 & 4 & 1.1 & 4 & 1.3 \\
\hline Puławy (14) & 2 & 0.8 & 1 & 0.4 & 11 & 3.8 & 22 & 6.2 & 11 & 3.1 & 21 & 6.8 \\
\hline Radzyń Podlaski (15) & 8 & 3.1 & 11 & 4.1 & 6 & 2.1 & 7 & 2.0 & 8 & 2.3 & 6 & 1.9 \\
\hline Ryki (16) & 10 & 3.9 & 6 & 2.2 & 11 & 3.8 & 12 & 3.4 & 7 & 2.0 & 5 & 1.6 \\
\hline Świdnik (17) & 3 & 1.2 & 9 & 3.3 & 10 & 3.5 & 15 & 4.2 & 10 & 2.8 & 10 & 3.2 \\
\hline Tomaszów Lub. (18) & 7 & 2.7 & 9 & 3.3 & 17 & 5.9 & 13 & 3.7 & 19 & 5.4 & 17 & 5.5 \\
\hline Włodawa (19) & 9 & 3.5 & 19 & 7.0 & 5 & 1.7 & 7 & 2.0 & 5 & 1.4 & 6 & 1.9 \\
\hline Zamość (20) & 23 & 8.9 & 24 & 8.9 & 30 & 10.4 & 36 & 10.1 & 28 & 8.0 & 25 & 8.1 \\
\hline Total (21) & 259 & 100 & 271 & 100 & 288 & 100 & 356 & 100 & 352 & 100 & 309 & 100 \\
\hline
\end{tabular}

$\%$ (percent) from whole number of deaths by suicide in studied period (year).

District, the highest number of suicide-related deaths occurred in 2004 (29), but it consistently fell until 2008 to reach 12 . The last 2 years again saw a slight increase in suicides. The Lublin District is one of the few districts with roughly similar suicide rates over the entire 10-year period. Only 2000-2002 and 2007 saw significantly lower rates. The Łęczna District's highest rate was recorded in 2000 [11], while the subsequent years brought a decrease until in 2007 no suicide was recorded in this area. The Łuków District's rate stayed at similar levels over a number of years. Drops were observed only in 2001 (8) and in 2007 (9). While analysing the suicide deaths in the Opole District, it should be noted that in 2001 the number of suicides was the highest (13), whereas in 2007 no suicide case was recorded. In Parczew, the suicide rate remained as a steady level, starting with 2000, with a significant drop recorded in 2010 when only one person committed suicide, while 2002 and 2007 brought higher-than-average rates. The Puławy District saw the lowest suicide rate in 2000-2001, while in 2003 the number of suicides increased ten-fold with
22 deaths recorded. In Radzyń Podlaski, from 2006, the number of suicide deaths continually increased to reach 14 in 2010. The Ryki District showed varying trends, with an increase in deaths by suicide every 2 years on average, followed by a significant decrease. The Świdnik District saw a rising rate from 2000 to reach 15 in 2003. Then, this number fell until 2007, only to double again in 2010. In Tomaszów Lubelski, the first 2 years of the study period were characterised by a low suicide rate, which was below 10 , and then in 2002 it rose to 17, and over the next years it remained at a similar level. Włodawa's highest rate was recorded in 2001 (19). From that point, the number fell rapidly and then stayed at a similar level, except for 2006 when only one suicide was recorded. The suicide rate in the Zamość District stayed at similar levels until 2006 (about 20-30 annually). In 2007 it fell to 5, rose considerably to 48 deaths in the following year, and then began to decrease.

A quantitative analysis of this phenomenon does not fully reflect its scale, as the districts vary in size and population. Therefore, the next step was to pro- 
Table 3. Deaths by suicide in individual districts of the Lubelskie Region in 2000-2010

\begin{tabular}{|c|c|c|c|c|c|c|c|c|c|c|c|c|c|}
\hline \multirow[t]{2}{*}{ District } & \multicolumn{2}{|c|}{2006} & \multicolumn{2}{|c|}{2007} & \multicolumn{2}{|c|}{2008} & \multicolumn{2}{|c|}{2009} & \multicolumn{2}{|c|}{2010} & \multicolumn{2}{|c|}{ Total } & \multirow{2}{*}{$\begin{array}{l}\text { Mortality rate } \\
\text { per } 100,000 \\
\text { inhabitants** }\end{array}$} \\
\hline & $n$ & $\%$ & $n$ & $\%$ & $n$ & $\%$ & $n$ & $\%$ & $n$ & $\%$ & $n$ & $\%^{*}$ & \\
\hline 1 & 21 & 7.6 & 23 & 10.0 & 19 & 6.4 & 22 & 7.1 & 9 & 3.2 & 267 & 8.3 & 13.3 \\
\hline 2 & 9 & 3.2 & 11 & 4.8 & 11 & 3.7 & 9 & 2.9 & 12 & 4.2 & 148 & 4.6 & 7.4 \\
\hline 3 & 16 & 5.8 & 15 & 6.5 & 9 & 3.0 & 16 & 5.2 & 7 & 2.5 & 270 & 8.3 & 13.5 \\
\hline 4 & 15 & 5.4 & 12 & 5.2 & 14 & 4.7 & 16 & 5.2 & 22 & 7.7 & 187 & 5.8 & 9.3 \\
\hline 5 & 4 & 1.4 & 3 & 1.3 & 1 & 0.3 & 1 & 0.3 & 0 & 0.0 & 31 & 1.0 & 1.5 \\
\hline 6 & 12 & 4.3 & 14 & 6.1 & 8 & 2.7 & 18 & 5.8 & 10 & 3.5 & 141 & 4.4 & 7.0 \\
\hline 7 & 5 & 1.8 & 14 & 6.1 & 15 & 5.0 & 5 & 1.6 & 8 & 2.8 & 129 & 4.0 & 6.4 \\
\hline 8 & 22 & 7.9 & 15 & 6.5 & 12 & 4.0 & 18 & 5.8 & 18 & 6.3 & 201 & 6.2 & 10.0 \\
\hline 9 & 52 & 18.8 & 29 & 12.6 & 46 & 15.4 & 49 & 15.9 & 42 & 14.7 & 443 & 13.7 & 22.1 \\
\hline 10 & 2 & 0.7 & 0 & 0.0 & 5 & 1.7 & 5 & 1.6 & 8 & 2.8 & 53 & 1.6 & 2.6 \\
\hline 11 & 22 & 7.9 & 9 & 3.9 & 18 & 6.0 & 23 & 7.4 & 34 & 11.9 & 213 & 6.6 & 10.6 \\
\hline 12 & 0 & 0.0 & 4 & 1.7 & 9 & 3.0 & 9 & 2.9 & 8 & 2.8 & 71 & 2.2 & 3.5 \\
\hline 13 & 4 & 1.4 & 7 & 3.0 & 3 & 1.0 & 4 & 1.3 & 1 & 0.4 & 44 & 1.4 & 2.2 \\
\hline 14 & 19 & 6.9 & 24 & 10.4 & 21 & 7.0 & 12 & 3.9 & 17 & 6.0 & 161 & 5.0 & 8.0 \\
\hline 15 & 6 & 2.2 & 11 & 4.8 & 11 & 3.7 & 13 & 4.2 & 14 & 4.9 & 101 & 3.1 & 5.0 \\
\hline 16 & 14 & 5.1 & 7 & 3.0 & 14 & 4.7 & 15 & 4.9 & 7 & 2.5 & 108 & 3.3 & 5.4 \\
\hline 17 & 9 & 3.2 & 4 & 1.7 & 12 & 4.0 & 10 & 3.2 & 18 & 6.3 & 110 & 3.4 & 5.5 \\
\hline 18 & 16 & 5.8 & 14 & 6.1 & 15 & 5.0 & 17 & 5.5 & 16 & 5.6 & 160 & 4.9 & 8.0 \\
\hline 19 & 1 & 0.4 & 10 & 4.3 & 8 & 2.7 & 6 & 1.9 & 4 & 1.4 & 80 & 2.5 & 4.0 \\
\hline 20 & 28 & 10.1 & 5 & 2.2 & 48 & 16.1 & 41 & 13.3 & 30 & 10.5 & 318 & 9.8 & 15.9 \\
\hline 21 & 277 & 100.0 & 231 & 100 & 299 & 100 & 309 & 100 & 285 & 100 & 3236 & 100 & - \\
\hline
\end{tabular}

$\%$ (percent) from whole number of deaths by suicide in studied period (year); *\% (percent) from whole number of deaths by suicide in studied 11 years in towns in the Lubelskie Region; ${ }^{* *}$ mortality rate (number of deaths by suicide in studied period by the average number of inhabitants for 11 years in the Lubelskie Region).

vide an analysis of suicides in selected district towns to present the phenomenon more clearly. In order to present the suicide phenomenon more accurately, the analysis covered towns and cities with populations ranging from 20 thousand to 349 thousand (Table 4).

In comparing the scale and trend in suicides over the study period in the selected towns and cities of the Lubelskie Region, the suicide rate per 1,000 residents was used with a view to illustrating the phenomenon more clearly. The data presented in Table 4 show that the highest suicide rates were found in towns with up to 20 thousand residents, such as Tomaszów Lubelski and Hrubieszów, and averaged 0.7/1,000. Another town with a high suicide rate is Zamość, where the rate was 0.3/1000 despite there being 66 thousand residents. In the remaining towns, the average rate did not exceed $0.2 / 1000$. It can be noted that the total number of suicide deaths in Zamość is very similar to that in Lublin, but in this city of 349 thousand resi- dents, the rate did not exceed $0.07 / 1,000$ on average. This is shown in Figure 2.

There is a noticeable rising trend in Tomaszów Lubelski and in Puławy, while a decrease can be observed in Biała Podlaska and in Kraśnik. Over the 11year study period, the rate was only subject to slight fluctuations in Lublin.

Another studied factor is the percentage of deaths by suicide by location type.

The analysis of the tendency of suicides over the period of 11 years in the area of the Lublin Region indicates its slight increase. Both in rural and in urban areas the mortality rate due to suicidal deaths in 2000 was lower than in 2010, which was the last year under examination. In urban areas the number of suicidal deaths in 2000 was approximately 12 per 100,000 residents, while in 2010 it increased to approximately 15 people. Rural areas proved to be more endangered with the risk of suicidal deaths according to the mor- 
Table 4. Suicides in selected towns and cities of the Lubelskie Region in absolute numbers and by suicide rate

\begin{tabular}{|c|c|c|c|c|c|c|c|c|c|c|c|c|c|c|c|c|c|c|}
\hline \multirow{3}{*}{ Year } & \multicolumn{18}{|c|}{ Town/city (population in thousands) } \\
\hline & \multicolumn{2}{|c|}{$\begin{array}{c}\text { Tomaszów } \\
\text { Lubelski } \\
(20,000)\end{array}$} & \multicolumn{2}{|c|}{$\begin{array}{c}\text { Hrubieszów } \\
(20,000)\end{array}$} & \multicolumn{2}{|c|}{$\begin{array}{l}\text { Bitgoraj } \\
(28,000)\end{array}$} & \multicolumn{2}{|c|}{$\begin{array}{l}\text { Kraśnik } \\
(35,000)\end{array}$} & \multicolumn{2}{|c|}{$\begin{array}{l}\text { Puławy } \\
(48,000)\end{array}$} & \multicolumn{2}{|c|}{$\begin{array}{c}\text { Biała } \\
\text { Podlaska } \\
(58,000)\end{array}$} & \multicolumn{2}{|c|}{$\begin{array}{l}\text { Zamość } \\
(66,000)\end{array}$} & \multicolumn{2}{|c|}{$\begin{array}{l}\text { Chetm } \\
(67,000)\end{array}$} & \multicolumn{2}{|c|}{$\begin{array}{c}\text { Lublin } \\
(349,000)\end{array}$} \\
\hline & $N$ & $R$ & $N$ & $R$ & $N$ & $R$ & $N$ & $R$ & $N$ & $R$ & $N$ & $R$ & $N$ & $R$ & N & $R$ & $N$ & $R$ \\
\hline 2000 & 3 & 0.15 & 15 & 0.75 & 6 & 0.2 & 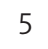 & 0.14 & 2 & 0.04 & 16 & 0.27 & 20 & 0.3 & 29 & 0.43 & 21 & 0.06 \\
\hline 2001 & 9 & 0.45 & 12 & 0.0 & 8 & 0.0 & 3 & .08 & 0 & 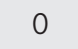 & 13 & 0. & 20 & . & 6 & .39 & 28 & 0.08 \\
\hline 2002 & 17 & 0.85 & 24 & 1.2 & 5 & 018 & 4 & 0.11 & 0 & 0 & 13 & 0 & 3 & 0 & 1 & 1 & 16 & 0 \\
\hline 2003 & 13 & 0.65 & 11 & 0.55 & 6 & 0.2 & 9 & 0.25 & 11 & 0.2 & 15 & 0.25 & 16 & 0.24 & 11 & 0.16 & 31 & 0.09 \\
\hline 2004 & 19 & 0.95 & 16 & 0.8 & 4 & 0.14 & 6 & 0.17 & o & 0.16 & 7 & 0.12 & 12 & 0.18 & 16 & 0.23 & 31 & 0.09 \\
\hline 2005 & 17 & 0 & 12 & 0 & 4 & 0.14 & 9 & 0.25 & 9 & 0.18 & 15 & 0.25 & 23 & 0.35 & 11 & 0.16 & 1 & 0. \\
\hline 2006 & 16 & 0.8 & 14 & 0.7 & 1 & 05 & 2 & 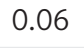 & 10 & 0.2 & 13 & 0.22 & 22 & 03 & 4 & 0.06 & 35 & 0 \\
\hline 2007 & 14 & 0.7 & 12 & 0.6 & 6 & 0.2 & 4 & 0.11 & 14 & 0.3 & 10 & 0.17 & 2 & 0.03 & 9 & 0.13 & 22 & 0.06 \\
\hline 2008 & 15 & 0.75 & 11 & ני. & 6 & 0.2 & 6 & 0.17 & 13 & 0.21 & J & 0.05 & 38 & 0.57 & J & 0.04 & 26 & 0.07 \\
\hline 2009 & 17 & 0.85 & 15 & 0.75 & 5 & 0.18 & 1 & 0.03 & 1 & 0.23 & 14 & 0. & 3 & 0 & 9 & 3 & 34 & 0 \\
\hline 2010 & 16 & 0.8 & 21 & 05 & 9 & 0.3 & 1 & .03 & 13 & 0.27 & 0 & 0 & 29 & 0.43 & 3 & 0.04 & 33 & 0.09 \\
\hline
\end{tabular}

$N$ - number of suicides, $R$ - suicide rate per 1,000 residents.

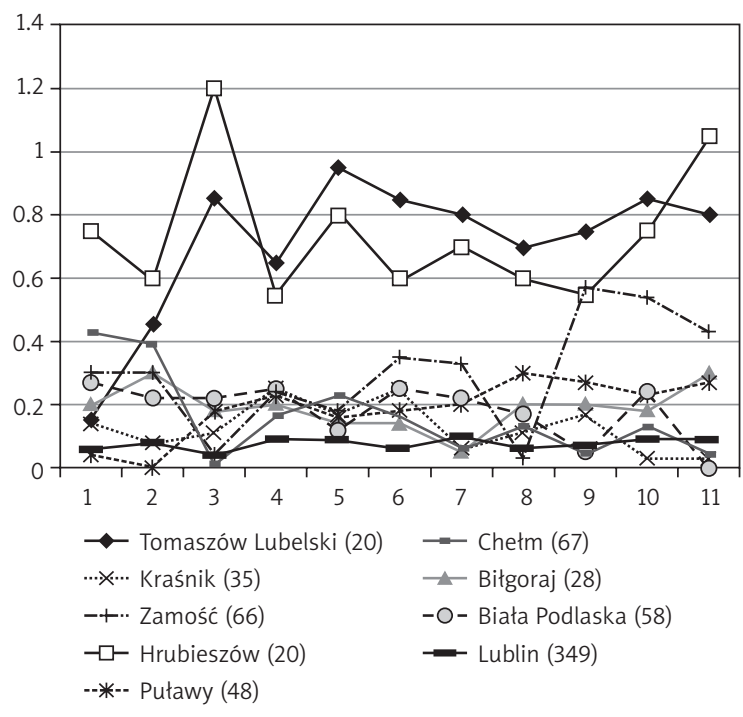

Figure 2. Suicide rate per 1000 residents in selected towns of the Lubelskie Region in 2000-2010

tality rate. At the beginning of the century, the number of deaths in rural areas was approximately 14 deaths per 100,000 residents, whereas the data collected until 31 December 2010 showed the rise in number to approximately 18 . In the period under examination, the increase in the number of suicidal deaths in urban areas was observed in 2003 and 2009. Such a tendency was also observed in rural areas of the Lublin Region in 2004 and 2008 (respectively approximately 21 suicidal deaths per 100,000 residents in these years). In 2007 in both groups of population a slight decrease in the number of suicidal deaths was observed. In rural areas the number fell from 18 deaths per 100,000 residents in 2006 to approximately 14, whereas in urban areas the number fell by approximately 1 case of suicidal deaths. Over the period of 11 years the mortality rate due to suicidal deaths in particular categories of location varied slightly. The average value of the mortality rate due to suicidal deaths in urban areas $(\mathrm{M}=14.26)$ was lower than in rural areas $(\mathrm{M}=17.98)$. The deviation of the values of the rates for both categories of location differed slightly. However, no significant differences were observed as for the average values of the mortality rate (urban areas $-\mathrm{SD}=1.84$; rural areas $-\mathrm{SD}=2.45$ ). The tendency of this phenomenon is at a similar level. No rapid increase or decrease in the number of suicides was reported (Table 5, Figure 3). The comparison of the data provided by the Lublin Municipal Police and the calculation of the mortality rate were made possible owing to the data provided by the Statistical Office in Lublin in the brochure Population and Natural Migration in the Lublin Reg7ion [8] as well as the data from NSP 2011 published by the Central Statistical Of7fi11ce [7, 11].

Another stage in the study aimed at defining the risk group by sex.

In the line chart under analysis presenting the mortality rate due to suicidal deaths by sex of the subjects, there is a clear difference between the two groups. The mortality rates for men in each of the periods under examination is far higher than the value for women. The value of the mortality rate for men is also characterised by a higher standard deviation $(\mathrm{SD}=3.3$ ) against the 
Table 5. Deaths by suicide by location type in the Lubelskie Region in 2000-2010

\begin{tabular}{|c|c|c|c|c|c|c|c|c|}
\hline \multirow[t]{2}{*}{ Year } & \multicolumn{4}{|c|}{ Village } & \multicolumn{4}{|c|}{ Town } \\
\hline & $n$ & $\%$ & Inhabitants & $\begin{array}{c}\text { Mortality rate } \\
\text { per } 100,000 \\
\text { inhabitants }\end{array}$ & $n$ & $\%$ & Inhabitants & $\begin{array}{c}\text { Mortality rate } \\
\text { per } 100,000 \\
\text { inhabitants }\end{array}$ \\
\hline 2000 & 169 & 58.7 & 1177324 & 14.4 & 119 & 41.3 & 1028876 & 11.6 \\
\hline 2001 & 186 & 59.4 & 1175483 & 15.8 & 127 & 40.5 & 1026237 & 12.4 \\
\hline 2002 & 202 & 61.4 & 1172374 & 17.2 & 127 & 38.6 & 1024618 & 12.4 \\
\hline 2003 & 230 & 57.6 & 1169810 & 19.7 & 169 & 42.3 & 1021362 & 16.5 \\
\hline 2004 & 251 & 60.5 & 1165164 & 21.5 & 162 & 39.0 & 1019992 & 15.9 \\
\hline 2005 & 227 & 59.3 & 1162746 & 19.5 & 155 & 40.4 & 1016865 & 15.2 \\
\hline 2006 & 206 & 59.7 & 1159717 & 17.8 & 135 & 39.1 & 1013049 & 13.3 \\
\hline 2007 & 165 & 55.9 & 1157557 & 14.3 & 128 & 43.1 & 1008656 & 12.7 \\
\hline 2008 & 242 & 60.8 & 1155800 & 20.9 & 153 & 38.4 & 1006032 & 15.2 \\
\hline 2009 & 219 & 56 & 1153282 & 19.0 & 168 & 43.0 & 1003920 & 16.7 \\
\hline 2010 & 206 & 57.4 & 1165575 & 17.7 & 151 & 41.9 & 1013036 & 14.9 \\
\hline Average & 209.4 & 58.8 & - & - & 144.9 & 40.7 & - & - \\
\hline \multicolumn{5}{|c|}{${ }^{*} M=17.98 ; S D=2.45$} & \multicolumn{4}{|c|}{${ }^{*} M=14.26 ; S D=1.84$} \\
\hline
\end{tabular}

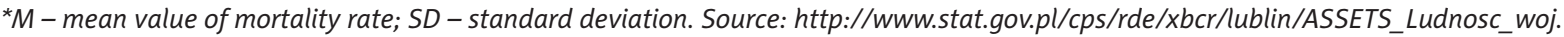
lubelskie_2011.

average value $(\mathrm{M}=23.96)$ than the values of the mortality rate among women $(\mathrm{M}=3.51$; $\mathrm{SD}=0.58)$. Over the period of 11 years, the mortality rate due to suicidal deaths for men varied from 20.2/100,000 (2000) to 29.6/100,000 (2003) in the Lublin region. At the same time the value of the mortality rate for women varied from $2.8 / 100,000$ to $4.8 / 100,000$ (2005) in the region of Lublin. The highest number of deaths among men was reported in 2003, when 30 per 100,000 men committed suicide. The same trend was observed in the next year, 2004 (mortality rate: 28.9/100,000 men). Among women the tendency was 8 times lower in 2003 and nearly 10 times lower in 2004 as compared to the opposite sex. In the female population the lowest number of suicidal deaths - approximately 3 deaths per 100,000 female residents of the Lublin region - was reported in the years 2002, 2004, 2006, 2007, 2010. The analysis of the two extreme periods indicates an increasing tendency of suicidal deaths among men. The mortality rate at the beginning of the period under examination was approximately 20 suicidal deaths per 100,000 men in the Lublin region, while on 31 December 2010 the number increased to 24 suicides in the group under analysis. The opposite sex shows a reverse trend. The mortality rate due to suicidal deaths among the female population decreased slightly from 3.7/100,000 women in 2000 to $2.8 / 100,000$ women in 2010 . The exact statistics are presented in Table 6 and Fi7gu11re 4 [7, $11]$.

Another significant factor in the study was the age profile of the suicide victims. As in the available statis-

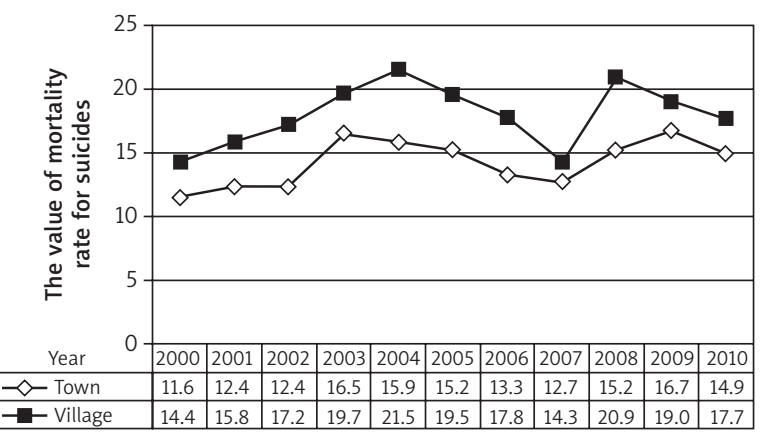

Figure 3. Mortality rate for suicide by location type in the Lubelskie Region in 2000-2010

tical material for the first 3 years the division into age groups was different from that used in the remaining years, the analysis was performed in two stages.

Over the course of 3 years, the highest average suicide rate referred to people from 31 to 50 years of age (42.8\%), and 51 to 70 (23.8\%), while the lowest suicide rate applied to children up to 14 years old (1.3\%) and over $15(1.7 \%)$, which is illustrated by Figure 5 .

In 2000-2002, the age group with the highest number of deaths related to suicide was formed by 31-50-year-olds. The largest proportion for this group was recorded in 2002 (45.8\%). The next group was 51-70, which in 2000 and 2002 recorded $24.7 \%$ and $24.6 \%$, respectively. $21-30$-year-olds were responsible for $15.5 \%$ of all suicides in 2001, while the percentage decreased to $11.8 \%$ in 2002 . The largest proportion of 
Table 6. Deaths by suicide in the Lubelskie Region in 2000-2010 including gender

\begin{tabular}{|c|c|c|c|c|c|c|c|c|}
\hline \multirow[t]{2}{*}{ Year } & \multicolumn{4}{|c|}{ Male } & \multicolumn{4}{|c|}{ Female } \\
\hline & $\begin{array}{l}\text { Death } \\
\text { number }\end{array}$ & $\%$ & $\begin{array}{l}\quad N \text { in } \\
\text { Lubelskie } \\
\text { Region }\end{array}$ & $\begin{array}{c}\text { Mortality rate } \\
\text { per } 100,000 \\
\text { inhabitants }\end{array}$ & $\begin{array}{l}\text { Death } \\
\text { number }\end{array}$ & $\%$ & $\begin{array}{l}\quad N \text { in } \\
\text { Lubelskie } \\
\text { Region }\end{array}$ & $\begin{array}{c}\text { Mortality rate } \\
\text { per } 100,000 \\
\text { inhabitants }\end{array}$ \\
\hline 2000 & 217 & 83.8 & 1072803 & 20.2 & 42 & 16.2 & 1133397 & 3.7 \\
\hline 2001 & 233 & 85.9 & 1070392 & 21.8 & 38 & 14.1 & 1131328 & 3.4 \\
\hline 2002 & 255 & 88.5 & 1067490 & 23.9 & 33 & 11.5 & 1129502 & 2.9 \\
\hline 2003 & 315 & 88.7 & 1064525 & 29.6 & 40 & 11.3 & 1126647 & 3.6 \\
\hline 2004 & 307 & 89.8 & 1061281 & 28.9 & 34 & 10.2 & 1123875 & 3.0 \\
\hline 2005 & 255 & 82.5 & 1058006 & 24.1 & 54 & 17.5 & 1121605 & 4.8 \\
\hline 2006 & 239 & 86.6 & 1053772 & 22.7 & 37 & 13.4 & 1118994 & 3.3 \\
\hline 2007 & 194 & 84 & 1049990 & 18.5 & 37 & 16 & 1116223 & 3.3 \\
\hline 2008 & 258 & 86.3 & 1047039 & 24.6 & 41 & 13.7 & 1114793 & 3.7 \\
\hline 2009 & 263 & 85.1 & 1044604 & 25.2 & 46 & 14.9 & 1112598 & 4.1 \\
\hline 2010 & 254 & 89.1 & 1056351 & 24.0 & 31 & 10.9 & 1122260 & 2.8 \\
\hline \multirow[t]{2}{*}{ Average } & 253.6 & 86.4 & & - & 39.4 & 13.6 & & - \\
\hline & \multicolumn{4}{|c|}{${ }^{*} M=23.96 ; S D=3.3$} & \multicolumn{4}{|c|}{${ }^{*} \mathrm{M}=3.51 ; \mathrm{SD}=0.58$} \\
\hline
\end{tabular}

$N$ - number of males or females in population in Lubelskie Region, ${ }^{\star} M-$ mean value of mortality rate; $S D-$ standard deviation. Source: http://www.stat.gov.pl/cps/rde/xbcr/lublin/ASSETS_Ludnosc_woj.lubelskie_2011.

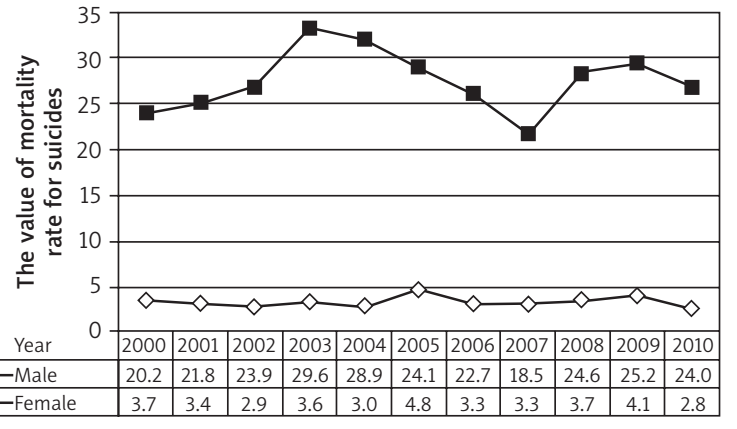

Figure 4. Mortality rate for suicide in the Lubelskie Region in 2000-2010 including gender

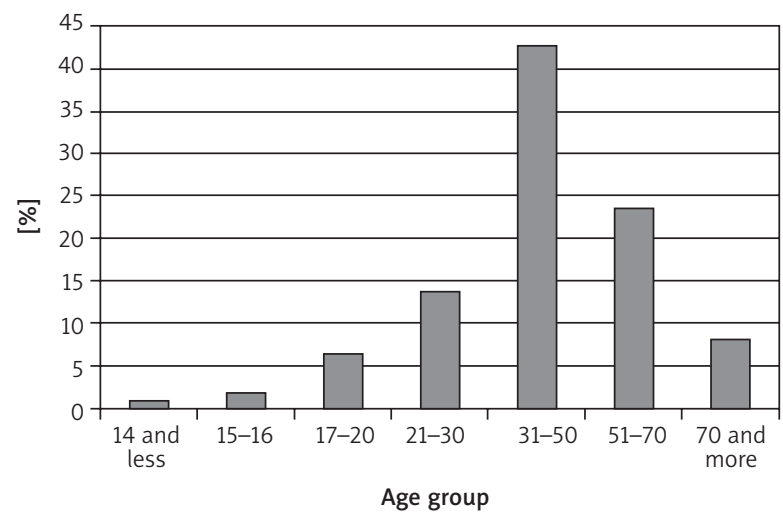

Figure 5. Average number of suicides by age group in the Lubelskie Region in 2000-2002
70 -year-olds was in 2000 (9.3\%), while in the group of $17-20$-year-olds it was $7 \%$ in 2001 . The highest proportion of suicides committed by young people was recorded in 2001 (2.6\%) in the group of 15-16-yearolds. In the group of 14-year-olds and less, the number of suicides stayed at a similar level. In 2000, it was $1.5 \%$, in 2001 it was $1.1 \%$ and in 2002 it was $1.4 \%$ of deaths (Table 7, Figure 5).

Figure 6 presents the proportion of various age groups in the total number of suicides in 2003-2010, showing the highest percentage of middle-aged people between 40 and 56 years old (Figure 7). In 2003 and 2006, the highest proportion was that of 40-49-yearolds $(25.9 \%$ and $27.9 \%$, respectively). In the remaining years, the highest proportion $(26.3 \%)$ of suicides was among 50-59-year-olds, in 2010. Deaths among 20-29-year-olds remained at a similar level between $14.8 \%$ and $17.8 \%$. In 2003-2005, the proportion of 30-39-year-olds remained at about 13\%, and in 2006 it fell to $9 \%$, to rise again in 2007 to $14.7 \%$. Among 60-69-year-olds, the highest percentage was recorded in 2005 (10.7\%), in 2007 (10.8\%), and in 2010 (12.3\%). 70 -year-olds represented $10.5 \%$ of all suicide victims in 2006. The highest percentage in total deaths by suicide committed by young people between 15 and 19 was recorded in 2007 (8.2\%) and in 2008 (8.3\%). This number nearly doubled in comparison to 2005 (4.8\%) and to 2006 (5.45\%). 14-year-olds constituted the smallest group as in 2003 they represented 1.1\% and in 2004 1.7\%. The next years saw a further de- 
Table 7. Deaths by suicide by age group in the Lubelskie Region in 2000-2002

\begin{tabular}{|c|c|c|c|c|c|c|c|c|c|c|c|c|c|c|}
\hline \multirow[t]{2}{*}{ Year } & \multicolumn{2}{|c|}{$\begin{array}{l}14 \text { years old } \\
\text { and less }\end{array}$} & \multicolumn{2}{|c|}{$\begin{array}{l}15-16 \text { years } \\
\text { old }\end{array}$} & \multicolumn{2}{|c|}{$\begin{array}{l}17-20 \text { years } \\
\text { old }\end{array}$} & \multicolumn{2}{|c|}{$\begin{array}{l}21-30 \text { years } \\
\text { old }\end{array}$} & \multicolumn{2}{|c|}{$\begin{array}{c}31-50 \text { years } \\
\text { old }\end{array}$} & \multicolumn{2}{|c|}{$\begin{array}{l}51-70 \text { years } \\
\text { old }\end{array}$} & \multicolumn{2}{|c|}{$\begin{array}{l}70 \text { years old } \\
\text { and more }\end{array}$} \\
\hline & $n$ & $\%$ & $n$ & $\%$ & $n$ & $\%$ & $n$ & $\%$ & $n$ & $\%$ & $n$ & $\%$ & $n$ & $\%$ \\
\hline 2000 & 4 & 1.5 & 4 & 1.5 & 17 & 6.6 & 39 & 15 & 105 & 40.5 & 64 & 24.7 & 24 & 9.3 \\
\hline 2001 & 3 & 1.1 & 7 & 2.6 & 19 & 7 & 42 & 15.5 & 113 & 41.7 & 60 & 22.1 & 21 & 7.7 \\
\hline 2002 & 4 & 1.4 & 3 & 1 & 19 & 6.6 & 34 & 11.8 & 132 & 45.8 & 71 & 24.6 & 22 & 7.6 \\
\hline Average & 3.5 & 1.3 & 4.7 & 1.7 & 18 & 6.7 & 38 & 14 & 117 & 42.8 & 65 & 23.8 & 22.3 & 8.2 \\
\hline
\end{tabular}

Table 8. Deaths by suicide by age group in the Lubelskie Region in 2003-2010

\begin{tabular}{|c|c|c|c|c|c|c|c|c|c|c|c|c|c|c|c|c|}
\hline \multirow[t]{2}{*}{ Year } & \multicolumn{2}{|c|}{$\begin{array}{l}14 \text { years old } \\
\text { and less }\end{array}$} & \multicolumn{2}{|c|}{$\begin{array}{l}\text { 15-19 years } \\
\text { old }\end{array}$} & \multicolumn{2}{|c|}{$\begin{array}{c}20-29 \\
\text { years old }\end{array}$} & \multicolumn{2}{|c|}{$\begin{array}{c}30-39 \\
\text { years old }\end{array}$} & \multicolumn{2}{|c|}{$\begin{array}{c}40-49 \\
\text { years old }\end{array}$} & \multicolumn{2}{|c|}{$\begin{array}{c}50-59 \\
\text { years old }\end{array}$} & \multicolumn{2}{|c|}{$\begin{array}{c}60-69 \\
\text { years old }\end{array}$} & \multicolumn{2}{|c|}{$\begin{array}{c}70 \text { years old } \\
\text { and more }\end{array}$} \\
\hline & $n$ & $\%$ & $n$ & $\%$ & $n$ & $\%$ & $n$ & $\%$ & $n$ & $\%$ & $n$ & $\%$ & $n$ & $\%$ & $n$ & $\%$ \\
\hline 2003 & 4 & 1.1 & 21 & 5.9 & 60 & 16.9 & 49 & 13.8 & 92 & 25.9 & 66 & 18.6 & 32 & 9 & 24 & 6.8 \\
\hline 2004 & 6 & 1.7 & 21 & 6.1 & 57 & 16.6 & 47 & 13.7 & 71 & 20.7 & 78 & 22.8 & 26 & 7.6 & 32 & 9.3 \\
\hline 2005 & 1 & 0.3 & 15 & 4.8 & 49 & 15.8 & 39 & 12.6 & 67 & 21.7 & 73 & 23.6 & 33 & 10.7 & 26 & 8.4 \\
\hline 2006 & 1 & 0.4 & 15 & 5.4 & 41 & 14.8 & 25 & 9 & 77 & 27.9 & 62 & 22.5 & 20 & 7.2 & 29 & 10.5 \\
\hline 2007 & 1 & 0.4 & 19 & 8.2 & 35 & 15.1 & 34 & 14.7 & 40 & 17.3 & 54 & 23.4 & 25 & 10.8 & 20 & 8.6 \\
\hline 2008 & 2 & 0.7 & 25 & 8.3 & 47 & 15.7 & 45 & 15 & 55 & 18.4 & 72 & 24 & 28 & 9.4 & 25 & 8.4 \\
\hline 2009 & 1 & 0.3 & 21 & 6.8 & 55 & 17.8 & 50 & 16.2 & 56 & 18.1 & 78 & 25.2 & 26 & 8.4 & 22 & 7.1 \\
\hline 2010 & 0 & 0 & 13 & 4.6 & 45 & 15.8 & 39 & 13.7 & 51 & 17.9 & 75 & 26.3 & 35 & 12.3 & 27 & 9.5 \\
\hline Average & 2 & 0.7 & 18.8 & 6.2 & 49 & 16.2 & 41 & 13.6 & 64 & 21.1 & 69.8 & 23.2 & 28.1 & 9.3 & 25.6 & 8.5 \\
\hline
\end{tabular}

crease in the proportion of this group, to $0.3-0.4 \%$. 2007 saw a slight increase to $0.7 \%$, but it was followed by another fall, with $0.3 \%$ in 2009 , and no case was recorded in 2010 (Table 8 , Figure 7).

To summarise the age analysis of self-destructive behaviours, it can be noted that the proportion of children in the total number of suicide victims is decreasing. The number of deaths among young people in the age groups $20-29,30-39$, and $70+$ is variable. There was a decreasing trend in the 40-49 group, while in 51-59-year-olds a consistent increase was observed.

Another factor of analysis was the educational level of people who attempted suicide. The available statistical material for the first 3 years involved total suicide attempts, while from 2003 there was a division into total suicide attempts and deaths by suicide, and from 2003 the data in the table represents deaths.

An analysis of the educational level of people who attempt suicide shows that the most at risk are people with primary education, with an average of $26.5 \%$, and those with basic vocational education, with an average of $18.2 \%$ (Figure 6).

The highest percentage in total suicide attempts was recorded in the years 2000 (31\%), 2001 (31.3\%), and 2002 (31.9\%), and then suicides in 2004 (30.4\%). The remaining years were similar, except for 2010

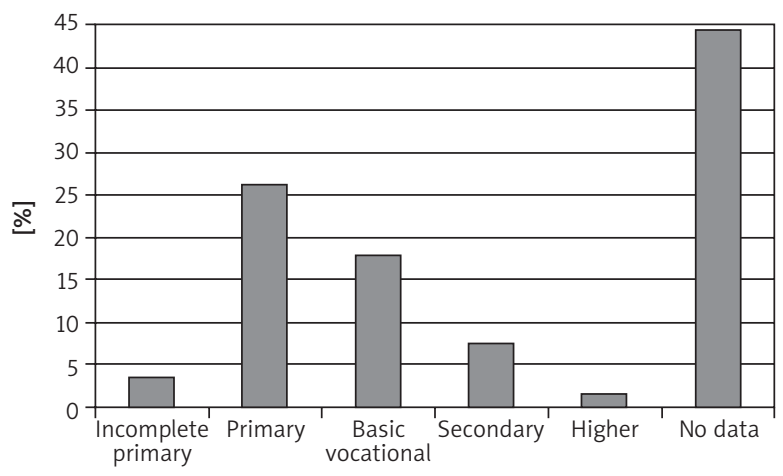

Figure 6. Average number of suicide attempts by educational level in the Lubelskie Region in 2000-2010

when the percentage of suicides committed by people with primary education fell to $15.4 \%$. The percentage of suicide attempts by people with vocational education ranged between 20.8 and $24.2 \%$. This group represented $21.6 \%$ of deaths by suicide in 2004 , which later continually decreased to reach $11 \%$ in 2009 and $13.7 \%$ in 2010

The next position in terms of the educational level was occupied by people with secondary education they comprised $7.7 \%$ of all suicides on average, and 


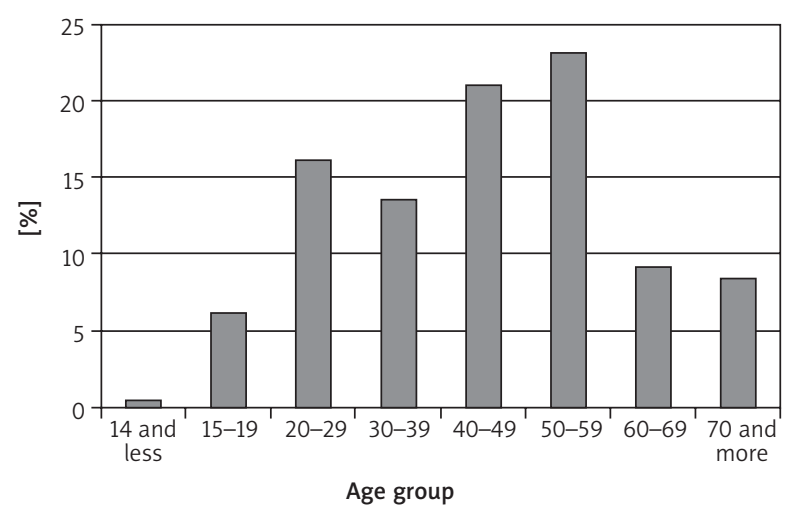

Figure 7. Average number of deaths by suicide in the Lubelskie Region in 2003-2010

this proportion remained the same for several years. People with higher education represented the lowest proportion of all people who attempted suicide and died by suicide, and their percentage in the total number of deaths in the study period was $1.8 \%$ on average. In an average of $44.7 \%$ of all cases, no data were collected on the educational level of the victims (Table 9, Figure 6).

The next stage in the study involved an analysis of the method of suicide chosen. These data are shown in Table 10.

Among the ways to take one's own life, the prevalent one is hanging. Over the 11 years of the study period, hanging was the method in $81.35 \%$ of suicides, and the highest percentage was recorded in 2003 (86.5\% of all suicides). Another, but much less frequent, method was jumping from a height, which was most often chosen in 2004 and 2005 (6.5\% and 6.3\% of suicides, respectively). The least popular methods were self-mutilation (2.5\% on average) and sleeping pills intake (2\%). The increasing number of cases of self-mutilation and pharmacological agent intake in relation to the initial period should be noted. Other methods comprised $6.15 \%$ of all attempts (Table 10).

Suicide is an individual phenomenon, caused by various events, illnesses and disorders, and by various social and environmental factors. In order to study suicidal behaviour in depth, it is necessary to analyse the causes of suicide, which allows the determination of suicidal risk groups (Table 11).

One of the most prevalent causes of suicide was mental disease, accounting for $15.1 \%$ of all attempts made within the analysed 11 years. 2003 and 2009, with $17 \%$ for each, saw the largest percentage of suicidal acts committed by the mentally ill. In the last 2 years subject to analysis, one can observe a strong downward tendency related to the suicides among mentally ill people. Family problems constituted the second most frequent cause. The average percentage of suicide deaths within 10 years was $11.7 \%$, with the largest one (16.4\%) recorded in 2002 and the smallest one $(9.2 \%)$ in 2009 . The last analysed years show a significantly lower proportion of family problems as a suicide trigger. Another risk group prone to suicidal behaviour comprised chronically ill people. They accounted for $6.7 \%$ of the overall number of suicides observed within the 10 -year period. Economic problems were the average cause of $5.1 \%$ of all suicidal acts. The largest percentages of suicide attempts prompted by chronic illness were recorded in 2000 (9.4\%) and in $2004(10.4 \%)$. The subsequent years revealed a downward pattern in this area. While 2002 was marked by the highest proportion of suicide attempts due to

Table 9. Suicide attempts and deaths by educational in the Lubelskie Region in 2000-2010

\begin{tabular}{|c|c|c|c|c|c|c|c|c|c|c|c|c|}
\hline \multirow[t]{2}{*}{ Year } & \multicolumn{2}{|c|}{$\begin{array}{l}\text { Incomplete } \\
\text { primary }\end{array}$} & \multicolumn{2}{|c|}{ Primary } & \multicolumn{2}{|c|}{ Basic vocational } & \multicolumn{2}{|c|}{ Secondary } & \multicolumn{2}{|c|}{ Higher } & \multicolumn{2}{|c|}{ No data } \\
\hline & $n$ & $\%$ & $n$ & $\%$ & $n$ & $\%$ & $n$ & $\%$ & $n$ & $\%$ & $n$ & $\%$ \\
\hline 2000 & 25 & 8.6 & 90 & 31 & 60 & 20.8 & 19 & 6.5 & 4 & 1.3 & 90 & 31 \\
\hline 2001 & 19 & 6 & 98 & 31.3 & 76 & 24.2 & 29 & 9.2 & 7 & 2.2 & 84 & 26.8 \\
\hline 2002 & 17 & 5.1 & 105 & 31.9 & 75 & 22.8 & 25 & 7.5 & 6 & 1.8 & 101 & 30.7 \\
\hline 2003 & 13 & 3.6 & 93 & 26.1 & 68 & 19.1 & 28 & 7.8 & 4 & 1.1 & 149 & 42 \\
\hline 2004 & 21 & 6.1 & 104 & 30.4 & 74 & 21.6 & 26 & 7.6 & 3 & 0.8 & 114 & 33.3 \\
\hline 2005 & 13 & 4.2 & 72 & 23.3 & 44 & 14.2 & 23 & 7.4 & 9 & 2.9 & 148 & 47.9 \\
\hline 2006 & 12 & 4.3 & 72 & 26 & 37 & 13.4 & 24 & 8.7 & 3 & 1 & 128 & 46.4 \\
\hline 2007 & 7 & 3 & 42 & 18 & 34 & 14.7 & 21 & 9 & 4 & 1.7 & 123 & 53.2 \\
\hline 2008 & 7 & 2.3 & 78 & 26 & 47 & 15.7 & 15 & 5 & 7 & 2.3 & 145 & 48.5 \\
\hline 2009 & 7 & 2.2 & 56 & 18 & 34 & 11 & 22 & 7 & 7 & 0.3 & 183 & 59.2 \\
\hline 2010 & 5 & 1.7 & 44 & 15.4 & 39 & 13.7 & 15 & 5.2 & 4 & 1.4 & 178 & 62.5 \\
\hline Average & 13.3 & 3.7 & 77.6 & 26.5 & 53.5 & 18.2 & 22.5 & 7.7 & 5.3 & 1.8 & 131.2 & 44.7 \\
\hline
\end{tabular}


Table 10. Suicides by selected method in the Lubelskie Region in 2000-2010

\begin{tabular}{|ccccccccccc|}
\hline Year & \multicolumn{1}{c}{ Intake of sleeping pills } & \multicolumn{2}{c}{ Self-mutilation } & \multicolumn{2}{c}{ Jumping from a height } & \multicolumn{2}{c|}{ Hanging } & \multicolumn{2}{c|}{ Other } \\
\cline { 2 - 13 } & $n$ & $\%$ & $n$ & $\%$ & $n$ & $\%$ & $n$ & $\%$ & $n$ & $\%$ \\
2000 & 3 & 1 & 1 & 0.3 & 14 & 4.9 & 236 & 81.9 & 24 & 8.3 \\
2001 & 7 & 2.2 & 6 & 1.9 & 5 & 1.6 & 269 & 85.9 & 19 & 6 \\
2003 & 8 & 2.4 & 4 & 1.2 & 10 & 3 & 279 & 84.8 & 21 & 6.4 \\
2004 & 4 & 0.5 & 6 & 1.7 & 21 & 5.3 & 345 & 86.5 & 19 & 4.7 \\
2005 & 7 & 1.8 & 12 & 3.1 & 24 & 6.3 & 291 & 75.9 & 34 & 8.9 \\
2006 & 7 & 2 & 11 & 3.2 & 16 & 4.6 & 281 & 81.4 & 22 & 6.4 \\
2007 & 14 & 4.7 & 11 & 3.7 & 11 & 3.7 & 232 & 78.6 & 18 & 6.1 \\
2008 & 10 & 2.5 & 15 & 3.8 & 22 & 5.5 & 312 & 78.4 & 22 & 5.5 \\
2009 & 5 & 1.3 & 15 & 3.8 & 17 & 4.3 & 318 & 81.5 & 16 & 4.1 \\
2010 & 10 & 2.8 & 7 & 1.9 & 15 & 4.2 & 291 & 81 & 18 & 5 \\
Average & 7 & 2.01 & 9.4 & 2.56 & 16.5 & 4.54 & 289.3 & 81.35 & 21.7 & 6.15 \\
\hline
\end{tabular}

Table 11. Causes of deaths by suicide in 2000-2010 in the Lubelskie Region

\begin{tabular}{|c|c|c|c|c|c|c|c|c|c|c|c|c|c|c|c|c|c|c|c|c|}
\hline \multirow[t]{2}{*}{ Year } & \multicolumn{2}{|c|}{$\begin{array}{c}\text { Mental } \\
\text { illness }\end{array}$} & \multicolumn{2}{|c|}{$\begin{array}{c}\text { Chronic } \\
\text { illness }\end{array}$} & \multicolumn{2}{|c|}{$\begin{array}{l}\text { Family } \\
\text { problems }\end{array}$} & \multicolumn{2}{|c|}{$\begin{array}{l}\text { Disappo- } \\
\text { intment } \\
\text { in love }\end{array}$} & \multicolumn{2}{|c|}{$\begin{array}{l}\text { Econo- } \\
\text { mic } \\
\text { condi- } \\
\text { tions }\end{array}$} & \multicolumn{2}{|c|}{$\begin{array}{l}\text { Pro- } \\
\text { blems } \\
\text { at } \\
\text { school }\end{array}$} & \multicolumn{2}{|c|}{$\begin{array}{l}\text { Loss } \\
\text { of the } \\
\text { source } \\
\text { of income }\end{array}$} & \multicolumn{2}{|c|}{$\begin{array}{l}\text { Death of } \\
\text { a close } \\
\text { friend or } \\
\text { relative }\end{array}$} & \multicolumn{2}{|c|}{ Other } & \multicolumn{2}{|c|}{$\begin{array}{l}\text { Undeter- } \\
\text { mined }\end{array}$} \\
\hline & $n$ & $\%$ & $n$ & $\%$ & $n$ & $\%$ & $n$ & $\%$ & $n$ & $\%$ & $n$ & $\%$ & $n$ & $\%$ & 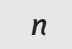 & $\%$ & $n$ & $\%$ & $n$ & $\%$ \\
\hline 00 & 47 & 16.3 & 27 & 9.4 & 5 & 12.1 & 12 & 4 & 4 & 4.8 & 7 & 2.4 & 7 & & & 1 & 37 & 12.8 & 130 & 45.1 \\
\hline 01 & 39 & 12.5 & 23 & 7.3 & 43 & 13.7 & 7 & 27 & 12 & 4.1 & 7 & 27 & 17 & 3.8 & 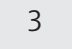 & 0.9 & 0 & 12.8 & 140 & 44.7 \\
\hline רחم2 & 53 & 16.1 & 18 & 5.5 & 54 & 16.4 & 11 & 33 & 34 & 10.3 & 3 & 0.9 & & 33 & & 15 & 14 & 13.4 & 134 & 40.7 \\
\hline 2003 & 68 & 17 & 29 & 7.3 & 43 & 10 & 7 & 0 & 21 & 5.2 & 4 & 1 & 7 & 17 & 10 & 2.5 & 49 & 12.3 & 188 & 47.1 \\
\hline A & 5 & 13.2 & 43 & 10.4 & 44 & 6 & 17 & 4 & 22 & 53 & 8 & 19 & 6 & 1.4 & 4 & 0.9 & 55 & 13.2 & 195 & 46.9 \\
\hline 2005 & 68 & 17.7 & 24 & 6) & 50 & & 2 & 5 & 18 & 4.7 & 4 & 1 & 3 & 0 & 5 & 1.3 & 3 & 11.2 & 171 & 44. \\
\hline 006 & 56 & 16.2 & 18 & 5.2 & 43 & 12.5 & 16 & 46 & 15 & 4.3 & 6 & 17 & 7 & ? & 10 & 2.9 & 46 & 13 & 151 & 43.8 \\
\hline 2007 & 48 & 16.3 & 23 & 7.8 & 3 & 11.2 & 20 & 6 & 10 & 3.4 & 2 & 06 & 7 & 2.4 & 5 & 1.7 & 36 & 12.2 & 126 & 42.7 \\
\hline 2008 & 68 & 17 & 20 & 5 & 4 & 11 & 27 & 6.8 & 20 & 5 & 6 & 1.5 & 1 & 0.2 & 5 & 1.2 & 45 & 11.3 & 184 & 46.2 \\
\hline 2009 & 45 & 11.5 & 16 & 4.1 & 36 & 9.2 & 26 & 6.6 & 21 & 5.4 & 7 & 1.8 & 5 & 13 & 10 & 2.6 & 46 & 11.8 & 201 & 51. \\
\hline 2010 & 43 & 11.9 & 22 & 6.1 & 36 & 0 & 13 & 3.6 & 14 & 3.9 & 0 & 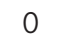 & . & 1.7 & 3 & 0.8 & 46 & 12.8 & 196 & 54.6 \\
\hline Average \% & & 15.1 & & 6.8 & & 11.9 & & 4.3 & & 5.1 & & 1.4 & & 1.9 & & 1.6 & & 12.4 & & 46.2 \\
\hline
\end{tabular}

economic problems (10.3\%), in the subsequent years it dropped by a half. In $2007,6.8 \%$ of the analysed individuals committed suicide due to disappointment in love, and this trend went on for the next 2 years. On average, disappointment in love was a factor in $4.3 \%$ of suicide attempts. Problems at school were found to be one the rarest reasons for killing oneself, accounting for $2.4 \%$ and $2.2 \%$ of suicides in 2000 and 2001 , respectively. This is due to a small proportion in the overall number of suicides of people who were of school age. The subsequent years saw a drop by a half in this area. These percentages rose again in 2004 and in 2006. Two percent of the analysed suicides were prompted by the loss of the source of income. The 
most significant rise in this percentage took place in 2001 and in 2002, as it reached $3.8 \%$ and 3.3\%, respectively. 2008 saw the smallest percentage of suicides caused by the loss of the source of income. $1.5 \%$ people took their life due to the death of a close friend or relative. The first 3 analysed years showed no significant changes in this respect. The percentage increased in 2003 (2.5\%), in 2006 (2.9\%) and in 2009 (2.6\%). The analysis revealed that in nearly half (46\%) of the cases, the suicide cause remained undetermined (Table 11).

\section{Conclusions}

It is of extreme importance to systematically analyse suicidal trends in order to keep pace with the dynamic changes in the social, political and economic conditions which determine the living standards and public health, and also to identify the social pathologies of contemporary civilisation [12]. For preventionrelated purposes, it is important to identify the factors with a potential to increase or reduce the risk of suicide, to determine the suicide risk groups based on social and demographic criteria, to recognise mental disease as the major suicide risk factor, to study the impact of somatic diseases and general medical factors which can be responsible for higher exposure to suicidal behaviour, and, last but not least, to examine what factors can protect against the reference behaviour [13, 14]. Systematic analyses should take place in order to develop special prevention programmes for the identified highrisk groups, and also effective support should be provided to families and individuals who are exposed to suicidogenic behaviour in their environment $[15,16]$. It is particularly important to promote mental health in different communities, to prevent mental disorders, to foster mentally healthy behaviour and lifestyle [4]. To develop coping strategies for mentally oppressive circumstances, to support families and elderly people, and also to foster the healthy psychological and sociological development of children and young people and to counteract social pathology $[17,18]$. This should entail establishing appropriate facilities to provide counselling and assistance in emergency situations. There is a challenge for the prevention of the phenomenon, which should take suicidal risk factors into consideration.

\section{Conflict of interest}

The authors declare no conflict of interest.

\section{References}

1. Hołyst B. Informacja o Światowym Dniu Zapobiegania samobójstwom - Światowy Dzień Zapobiegania Samobójstwom - 10 września 2008 roku. Suicydologia 2008; 4.

2. Hołyst B. Suicydologia 2008-2010.

3. Grajda A, Kułaga Z, Wójcik P, Jakubowska-Winecka A, Napieralska E. Zmienne ekonomiczne a umieralność mło- dzieży z powodu samobójstw w Polsce w latach 1999-2006. Standardy Medyczne 2010; 7: 14.

4. Czabała JC, Danielewicz D, Hryniewicka A, Rola J, Zasępa E. Promocja zdrowia psychicznego jako działania zapobiegające samobójstwom. Suicydologia 2008.

5. Główny Urząd Statystyczny. Departament Badań Demograficznych i Rynku Pracy. http://www.stat.gov.pl/cps/ rde/xbcr/gus/L_podst_inf_o_rozwoju_dem_pl_do_2012. pdf (Available at: 11.12.2013).

6. Główny Urząd Statystyczny. Departament Badań Demograficznych i Rynku Pracy. http://www.stat.gov.pl/PI_gus/ ludnosc piramida/start.htm (Available at: 14.12.2013).

7. Główny Urząd Statystyczny. Departament Badań Demograficznych i Rynku Pracy. http://www.stat.gov.pl/cps/ rde/xbcr/gus/lu_podsta_info_o_rozwoju_demograf_polski_2000-2009.pdf (Available at: 14.12.2013).

8. Urząd Statystyczny w Lublinie. Ludność, ruch naturalny i migracje w województwie lubelskim w $2011 \mathrm{r}$. http:// www.stat.gov.pl/cps/rde/xbcr/lublin/ASSETS_Ludnosc woj.lubelskie_2011\%281\%29.pdf (Available at: 14.12.2013).

9. Ministerstwo Zdrowia. http://www.mz.gov.pl/wwwfiles/ ma_struktura/docs/npoz_zdrpub_03112011.pdf (Available at: 15.07.2012).

10. Główny Urząd Statystyczny. Ludność, stan i struktura demograficzno-społeczna: http://www.stat.gov.pl/cps/rde/ xbcr/gus/ludnosc_stan_i_struktura_demograficzno_spoleczna.pdf (Available at: 11.12.2013)

11. Główny Urząd Statystyczny. Ludność, stan i struktura demograficzno-społeczna. Narodowy Spis Powszechny Ludności i Mieszkań 2011. http://www.stat.gov.pl/cps/ rde/xbcr/gus/LUD_ludnosc_stan_str_dem_spo_NSP2011. pdf (Available at: 14.12.2013).

12. Amerykańskie Towarzystwo Psychiatryczne. Ocena ryzyka i leczenie osób zagrożonych samobójstwem. Krótkie wytyczne postępowania. Suicydologia 2007; 3: 40-8.

13. Jarosz M. Samobójstwa w III Rzeczypospolitej w perspektywie światowej. Analiza socjologiczna. Suicydologia 2005; 1: 1-13.

14. Makara-Studzińska M, Turek R. Samobójstwo w chorobach somatycznych. Suicydologia 2005; 1: 51-4.

15. Pużyński S. Samobójstwa i depresje. Lęk i Depresja 1997; 2: 139-56.

16. Brodniak WA. Ocena ryzyka zachowań samobójczych wśród osób z zaburzeniami psychicznymi. Analiza porównawcza wybranych badań z lat 2000-2006. Suicydologia 2007; 3: 83-7.

17. Sulska E, Sumiła A. Zachowania samobójcze u dzieci i młodzieży hospitalizowanych psychiatrycznie. In: Psychopatologia okresu dorastania. Wybrane zagadnienia. Radziwiłłowicz W, Sumiła A (eds.). Oficyna Wydawnicza „Impuls”, Krakow 2006; 199-214.

18. Rosa K. Młodzież podejmująca próby samobójcze. Charakterystyka socjologiczna. Przegl Lek 2007; 1: 24-30.

\section{Address for correspondence:}

\section{Monika Kaczoruk}

Department of Public Health

Faculty of Health Sciences

Medical University of Lublin

ul. W. Chodźki 1, 20-093 Lublin, Poland

Phone: +48 814486722

E-mail: monika.kaczoruk@umlub.pl 